LIRA, RM; SILVA, EFF; SILVA, GF; SOARES, HR; WILLADINO, LG. 2018. Growth, water consumption and mineral composition of watercress under hydroponic system with brackish water. Horticultura Brasileira 36: 013-019. DOI - http://dx.doi.org/10.1590/S0102-053620180103

\title{
Growth, water consumption and mineral composition of watercress under hydroponic system with brackish water
}

\author{
Raquele M Lira; Ênio FF Silva; Gerônimo F Silva; Hammady R Soares; Lilia G Willadino
}

Universidade Federal Rural de Pernambuco (UFRPE), Recife-PE, Brazil; raquelelira@gmail.com; enio.fsilva@ufrpe.br; geronimo.silva@ ufrpe.br; hresoares@hotmail.com; willadino.lilia@gmail.com

\begin{abstract}
The underground water reserves in the semi-arid region present high salinity levels. However, the scarcity of the resource compels the use of this water for several human activities, including agriculture. The aim of this work was to evaluate the use of brackish water for watercress cultivation (Nasturtium officinale) in a hydroponic NFT system (laminar flow of nutrients) and effects on water consumption, growth, yield and nutrient extraction by the plant. We studied six levels of salinity $\left(0.2 ; 1.2 ; 2.2 ; 3.2 ; 4.2\right.$ and $\left.5.2 \mathrm{dS} \mathrm{m}^{-1}\right)$, in a completely randomized experimental design, with four replicates. Salinity was obtained by the addition of $\mathrm{NaCl}$ into the local water supply, being these waters used to prepare the nutrient solution and to replace the evapotranspirated water volume. We noticed a reduction in leaf area, fresh and dry mass of shoot, $\mathrm{K}$ content in plant and water consumption of the crop and, increased contents of $\mathrm{P}, \mathrm{Na}, \mathrm{Cl}$ in the plants, with increasing salinity of the solution. The use of brackish water for watercress cultivation in hydroponics is possible as an alternative for producers who have availability of brackish water and restricted possibility of fresh water. A reduction in dry mass of plants was observed with increasing electrical conductivity.
\end{abstract}

Keywords: Nasturtium officinale, nutrient solution, NFT system, salinity.

\section{RESUMO}

Crescimento, consumo hídrico e composição mineral de agrião cultivado em hidroponia com águas salobras

As reservas hídricas subterrâneas na Região Semiárida apresentam-se em grande parte com elevadas salinidades. Entretanto, a escassez do recurso obriga a utilização dessas águas para diversas atividades, inclusive para agricultura. Objetivou-se, com este trabalho, avaliar o uso de águas salobras no cultivo de agrião (Nasturtium officinale) em sistema hidropônico NFT (fluxo laminar de nutrientes) e os efeitos sobre o consumo hídrico, crescimento, rendimento e extração de nutrientes pela planta. Foram estudados seis níveis de salinidade da água $(0,2 ; 1,2 ; 2,2 ; 3,2 ; 4,2$ e $5,2 \mathrm{dS}$ $\mathrm{m}^{-1}$ ), no delineamento experimental inteiramente casualizado, com quatro repetições. A salinidade foi obtida pela adição de $\mathrm{NaCl}$ na água de abastecimento local, a qual foi utilizada no preparo da solução nutritiva e na reposição do volume evapotranspirado. Houve redução da área foliar, das massas fresca e seca da parte aérea, do teor de $\mathrm{K} \mathrm{e}$ do consumo hídrico da cultura e aumento dos teores de $\mathrm{P}, \mathrm{Na}$ e $\mathrm{Cl}$ na planta, com o aumento da salinidade da solução. É possível utilizar água salobra para a produção de agrião, em cultivo hidropônico, como alternativa para produtores que tenham disponibilidade de água salobra e restrita disponibilidade de água doce, porém com redução na massa seca com o incremento da condutividade elétrica da água.

Palavras-chave: Nasturtium officinale, solução nutritiva, sistema NFT, salinidade.

(Received on February 23, 2016; accepted on May 24, 2017)

$\mathrm{T}$ he problem of water scarcity in the world has been highlighted for several years, especially in countries with large semi-arid regions such as Brazil (Paulus et al., 2010). Considering superficial water scarcity, poor drinking water supply and heterogeneous temporal distribution of rainfall, which is typical in Brazilian semi-arid, the development of human activities becomes quite compromised. The consequences are serious economic and social impact, highlighting the importance of researches and generation of technologies which allow the use of brackish water for food production.

Hydroponic cultivation is an alternative to conventional farming practices, with some advantages for the consumer, producer and environment, such as obtaining good quality products, with a short cycle; higher productivity, lower use of water, inputs and labor (Paulus et al., 2012). Moreover, it is expected that the crops show more tolerance related to salinity than when growing under conventional system, due to constant availability of water in several kinds of hydroponic systems and insignificant matric potential contribution to total potential of water, representing a higher absorption of water and inputs by the plants for the same salt quantity (Soares et al., 2007).

Taking this hypothesis into account, in hydroponic cultivation, the crops, mainly the ones which show a short cycle, should promote the sustainable use of brackish water, due to the shorter period of exposure time to salt stress, resulting in the minimization of damage caused to plants by this stress. Thus, with the use of brackish water in hydroponic system, it is expected to grow crops of interest, with greater 
water and input use efficiency, lower environmental risk and less depletion of commercial income (Maciel et al., 2012).

Watercress (Nasturtium officinale) is a semi-perennial Brassicaceae, It is a creeping-stem, rustic and heat resistant plant. The species grows well in running water (Filgueira, 2008), which favors its cultivation in hydroponic system in high temperature regions. It is a crop of commercial interest such as the most vegetables and it has low caloric content $(22$ calories in each 100 $\mathrm{g})$. Being a rich source of vitamins A, $\mathrm{C}$ and $\mathrm{B}$ complex, and also iron, zinc, calcium and fiber, it also strengths the immune system, growth process, health of body tissues and production of red blood cells (Abracen, 2015).

In Brazil, watercress consumption has been increasing, due to its importance for food and human health (Ohse et al., 2012), it also stands out for being high-quality food. Nevertheless, information on the production of watercress in hydroponic systems with the use of brackish water is, still, very incipient (Gomes, 2009). Since it is a species which is able to survive in water and with a short cycle, a good production in saline hydroponic system is expected. Thus, this study is fundamentally important to improve the investments in hydroponic productions of this crop. So, researches on brackish water for watercress crop is extremely important, since the use of this water in the production of this vegetable can be an alternative of income for the farmer who only counts on this type of water on the property.

Given the above considerations, we aimed to evaluate the use of brackish water in water consumption, development, yield and in the nutrient extraction, by the watercress plant grown in hydroponic NFT system.

\section{MATERIAL AND METHODS}

The experiment was arranged at Agricultural Engineering Department of Federal Rural University of Pernambuco, in Recife ( $8^{\circ} 01^{\prime} 05^{\prime \prime} \mathrm{S}$; 34 $36^{\circ}$ ' $48^{\prime \prime} \mathrm{W}$; 6.5 $\mathrm{m}$ altitude). The plants were conducted in a greenhouse, presenting $7.0 \mathrm{~m}$ wide; $24.0 \mathrm{~m}$ in length; 3.0 ceiling height; 4.5 $\mathrm{m}$ central height and $0.2 \mathrm{~m}$ baseboard in reinforced concrete. The cover in arch type was a transparent low-density polyethylene film, anti UV additive 0.10 mm thick; the lateral and frontal walls were made with anti-aphid screens.

Six levels of water salinity $(0.2,1.2$, 2.2, 3.2, 4.2 and $5.2 \mathrm{dS} \mathrm{m}^{-1}$ ) were studied in a completely randomized design with four replications. The salinity was obtained by the addition of $\mathrm{NaCl}$ in the local water supply, which was used in the preparation of the nutrient solution and in the replacement of the evapotranspiration volume.

The hydroponic structure was composed of 24 plots, each one representing a NFT hydroponic system (laminar flow technique of nutrients), and similar to the description carried out by Soares et al. (2009). It contained a 60 L capacity plastic reservoir, a circulating electric pump and polypropylene hydroponic profiles, $75 \mathrm{~mm}$ commercial diameter, $3 \mathrm{~m}$ length, holes of $25 \mathrm{~mm}$ radius and $25 \mathrm{~cm}$ spacing between plants per and $30 \mathrm{~cm}$ between the profiles, being built four to four and spaced $80 \mathrm{~cm}$. The six central plants of the hydroponic profile were considered useful.

The profiles were installed at $85 \mathrm{~cm}$ height, having four points of support and slope of $5 \%$, to promote the running and drainage of the solution. The injected solution covered the slope profile with an average flow rate of $1.5 \mathrm{~L}$ per minute. A controller register regulated this flow. The excess that was not injected into the profile returned to the reservoir through the return pipe, favoring the aeration of the nutrient solution.

Individualized automatic supply systems were also set up for each plot (15 L capacity) for the replacement of evapotranspirated water. The suppliers were made of continuous-section PVC pipes with $15 \mathrm{~cm}$ diameter, fitted to a graduated ruler, attached to a transparent hose to read the water level, and connected to a faucet that provided the automatic water outlet to the nutrient solution reservoir.
The watercress seeds were placed to germinate in phenolic foam cells, $2 \times 2 \times 2 \mathrm{~cm}$, where twelve seeds were placed in each cell. After seeding, the cells were kept in the dark for 96 hours until emergence. Four days after sowing (DAS), the seedlings were transplanted to the nursery in NFT hydroponics in a greenhouse, being irrigated with $50 \%$ diluted nutrient solution (Furlani, 1998).

Irrigation of seedlings in the nursery and plants in the production phase was controlled by an electric timer programmed for 15-minute intervals between each irrigation, which also lasted 15 minutes between 7:00 and 18:00 h. From 6:00 p.m. to 7:00 a.m., the timer was programmed for irrigation every 2 hours, lasting 15 minutes each. At eight DAS, the thinning was done leaving five plants per cell. The seedlings continued in the nursery for fifteen days, being transplanted to the hydroponic profiles and submitted to recommended treatments with nutrient solution.

Each salinity level was prepared in a 240 L capacity water tank, measuring the electrical conductivity of the water (CEw) and $\mathrm{pH}$, then adding the macro and micronutrients for preparing the nutrient solution, according to Furlani (1998), for leafy vegetables. After homogenization, the $\mathrm{pH}$ and electrical conductivity of the nutrient solution (CEsol) were measured.

Readings of $\mathrm{pH}$ and CEsol were performed on alternate days. However, in order to simulate actual field conditions and assuming that the farmer does not provide material for such adjustment, $\mathrm{pH}$ correction to optimal range, from 5.5 to 6.5 , was not done. The the nutrient solution of the treatments was substituted whenever CEsol of the control treatment reached value less than $1.0 \mathrm{dS} \mathrm{m}^{-1}$.

In order to determine fresh and dry masses, after 20 DAS, plants were collected and separated into roots and shoots every five days. The shoot was weighed on a precision balance $(0.01$ g) and, then, dried in an oven with air forced circulation at $65^{\circ} \mathrm{C}$, for 96 hours. After dried, the shoot was crushed to determine contents of nitrogen $(\mathrm{N})$, phosphorus $(\mathrm{P})$, potassium $(\mathrm{K})$, 
calcium $(\mathrm{Ca})$, magnesium $(\mathrm{Mg})$, sulphur $(\mathrm{S})$, sodium $(\mathrm{Na})$ and chlorine $(\mathrm{Cl})$, according to the methodology proposed by Bezerra Neto \& Barreto (2011).

The leaf area was determined using SigmaScan software, using scanned leaves. The number of leaves per plant was obtained by individual counting. Absolute (TCA) and relative growth rates (TCR) in each harvest were obtained according to Benincasa (1988).

The water consumption daily and during the cycle was evaluated by readings made in the automatic suppliers and by later calculation of the evapotranspirated volume, according to Equation 1:

$$
V_{E t c}=\frac{(L f-L i) \times \pi \times D^{2}}{4 \times n \times \Delta T} \times 10^{6}
$$

Where: $\mathrm{V}_{\mathrm{Etc}}=$ evapotranspirated volume, in $\mathrm{mL}$ per plant; $\mathrm{Lf}=$ final reading of tank water level $(\mathrm{m})$; $\mathrm{Li}=$ initial reading of tank water level (m); $\mathrm{D}=$ inner diameter of the reservoir $(\mathrm{m})$; $\Delta T=$ interval between readings and $n=$ number of plants in the profile in the $\Delta \mathrm{T}$ time interval.

The results were submitted to analysis of variance by the F test and, when any significant effect for treatments was observed, the polynomial regression analysis was done using the statistical program SISVAR version 5.1.

\section{RESULTS AND DISCUSSION}

An increase in salinity level of nutrient solution was observed throughout the cycle (Figure 1A), except for $0.2 \mathrm{dS} \mathrm{m}^{-1}$, in which the nutrient solution was prepared using only water supply. This nutrient solution even showed a decrease in CEsol over time. This result was due to the fact that the nutrient uptake by the plants was higher than the salt accumulation in the used replacement water (Paulus et al., 2012).

The increase in the electrical conductivity of nutrient solution throughout the cycle, except for the control (Figure 1A), can be attributed to salt accumulation from the increase in water salinity level used to prepare the nutrient solution and to the lowest nutrient uptake in these levels. Although they worked with another leafy vegetable, Santos et al. (2010), Soares et al. (2010) and Alves et al. (2011) obtained results similar to the ones verified in this study, when producing hydroponic lettuce in brackish water.

In relation to $\mathrm{pH}$ of the nutrient solution (Figure 1B), the authors verified an oscillation between 5 and 6 , which means, $\mathrm{pH}$ remained within the

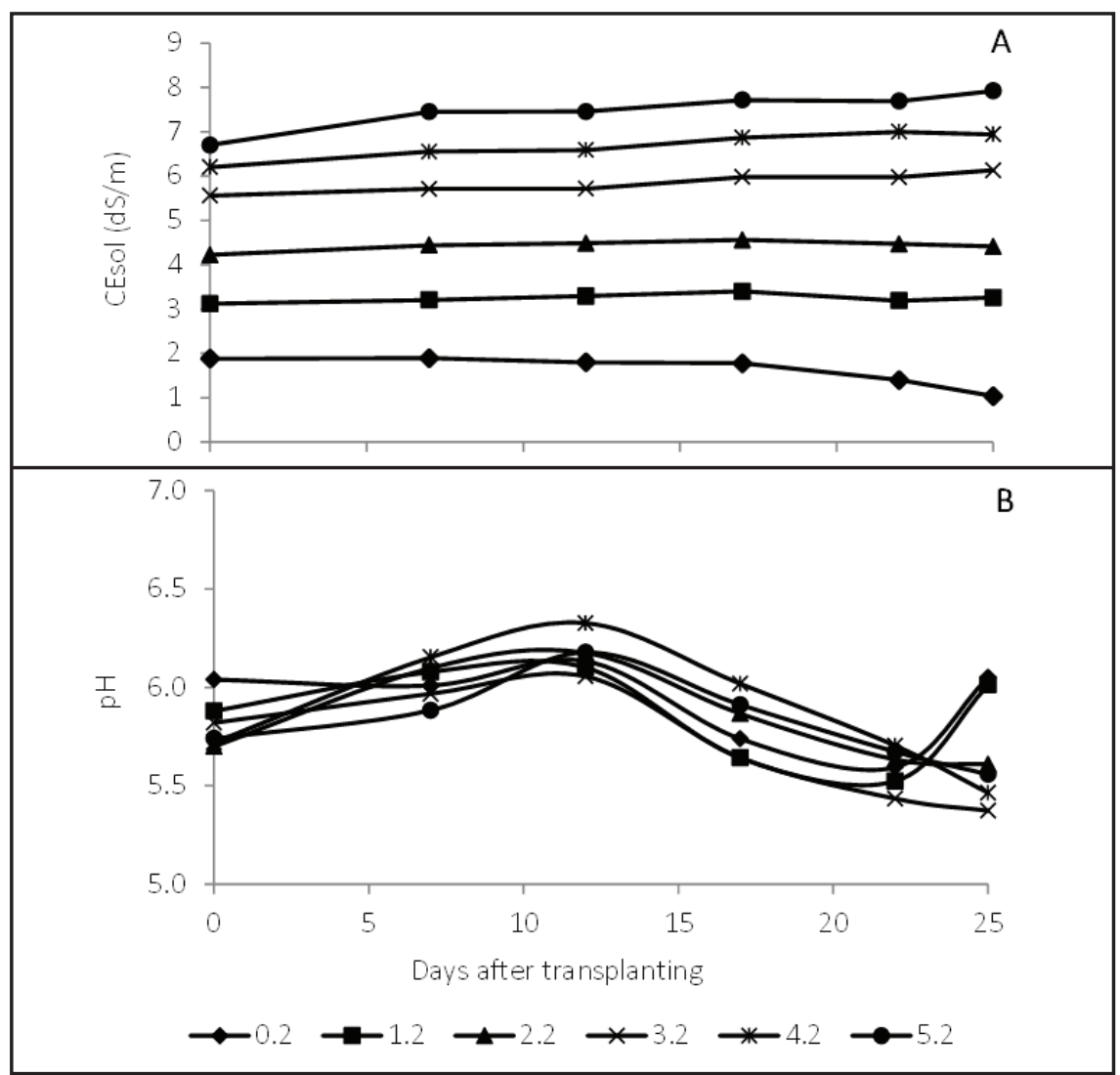

Figure 1. Average values of electrical conductivity (A) and $\mathrm{pH}(\mathrm{B})$ of the nutrient solution throughout the research. Recife, UFRPE, 2012.

Table 1. Summary of an analysis of variance and regression equations adjusted to the growth and analyzed yield traits of watercress plant, in relation to the levels of water salinity (CEw). Recife, UFRPE, 2012.

\begin{tabular}{|c|c|c|c|c|}
\hline Traits & F calculated & CV(\%) & Regression equation & $\mathbf{R}^{2}$ \\
\hline$\overline{\mathrm{AF}}$ & $13^{*}$ & 18.36 & $\mathrm{AF}=715.37-83.464 * * \mathrm{x}$ & 0.91 \\
\hline NF & $6.76^{\mathrm{ns}}$ & 11.3 & $\hat{y}=40.08$ & - \\
\hline MFPA & $35.53 * *$ & 10.36 & $\mathrm{MFPA}=41.695-4.5775 * \mathrm{x}$ & 0.87 \\
\hline MSPA & $20.10 * *$ & 11.56 & $\mathrm{MSPA}=2.4831-0.2483^{* * \mathrm{x}}$ & 0.96 \\
\hline TCAMF & $31.33 * *$ & 10.96 & $\mathrm{TCAMF}=2.6854-0.296^{* *} \mathrm{x}$ & 0.89 \\
\hline TCRMF & $2.33^{\mathrm{ns}}$ & 7.46 & $\hat{y}=0.23$ & - \\
\hline TCAMS & $9.94 * *$ & 15.9 & TCAMS $=0.1577-0.0155^{* *} \mathrm{x}$ & 0.98 \\
\hline TCRMS & $3.07 *$ & 6.64 & $\mathrm{TCRMS}=0.2555-0.007^{* *} \mathrm{x}$ & 0.88 \\
\hline TCANF & $17.71^{\mathrm{ns}}$ & 11.06 & $\hat{y}=6.91$ & - \\
\hline TCRNF & $2.29^{\text {ns }}$ & 16.18 & $\hat{y}=0.13$ & - \\
\hline
\end{tabular}

ns, $* *$ and $*$ : respectively, not significant, significant at 1 and $5 \%$ probability by $\mathrm{F}$ test; $\mathrm{AF}=$ leaf area; $\mathrm{NF}=$ number of leaves; MFPA and MSPA = fresh and dry masses of shoot, respectively; TCAMF and TCRMF=- absolute and relative growth rate of the fresh mass, respectively; TCAMS and TCRMS= absolute and relative growth rate of the dry mass, respectively; $\mathrm{TCANF}$ and TCRNF= absolute and relative growth rate of the number of leaves, respectively. 
optimal range for most crops (Maciel et al., 2012). According to Martinez (2002), if values lower than 4 are noticed, it is possible that plants lose some nutrients which were already absorbed, besides they show a delay in root growth, whereas values higher than 7.0 may cause precipitations of elements such as calcium, phosphorus, iron and manganese, which become unavailable.

The increase in nutrient solution salinity, with an increase in water salinity, affected negatively the leaf area (AF), shoot fresh mass (MFPA) and shoot dry mass (MSPA), absolute growth rate of fresh mass (TCAMF), absolute growth rate of dry mass (TCAMS) and relative growth rate of dry mass (TCRMS) (Table 1). The other evaluated traits of growth and yield, number of leaves (NF), relative growth rate of fresh mass (TCRMF), absolute growth rate (TCANF) and relative growth rate (TCRNF) for number of leaves did not show any significant effects of the treatments.

Decreases were noticed, with the unit increase in water salinity in $\mathrm{dS} \mathrm{m}^{-1}$, for AF, MFPA, MSPA, TCAMS and TCRMS in the order of $11.67 ; 10.97$; $10 ; 11.02 ; 9.82$ and $2.74 \%$, respectively (Table 1). The values for MFPA and MSPA found in this study are lower than the ones found by Gomes (2009), who grew large-leaved watercress in hydroponic NFT system using brackish water with a $\mathrm{CE}$ ranging from 3.5 and $9.5 \mathrm{dS} \mathrm{m}^{-1}$ to prepare the nutrient solution, obtaining loss of 7.28 and $7.78 \%$, respectively with a unit increase in water salinity. On the other hand, a significant effect of water salinity on MFPA, opposing to the lack of effect on the number of leaves (Table 1), shows a reduction in watercress leaf mass as a result of the reduction of leaf size, and not by failing to produce them, considering the reduction of leaf area as a consequence of the increase of water salinity in the treatment.

According to Silva Júnior (2007), the number of leaves is not always an ideal trait in order to indicate tolerance to salinity, since the plant may not show a reduction in number of leaves but still present a reduction in leaf area. Soares et al. (2010), studying lettuce cv. Verônica and six different levels of $\mathrm{NaCl}$ applied into the nutrient solution did not find effect on the number of leaves either, they verified a reduction in leaf mass as a result of reduction in leaf size, though.

Absolute growth rate of shoot and relative growth rate of dry mass of watercress decreased with an increase of salinity of water; the authors obtained the value of $0.2 \mathrm{dS} \mathrm{m}^{-1}$ for the lowest level of water salinity, the maximum value of $2.62 \mathrm{~g} \mathrm{day}^{-1}$ for TCAMF; $0.1546 \mathrm{~g} \mathrm{day}^{-1}$ for TCAMS and 0.2541 g day $^{-1}$ for TCRMS (Table 1). The reduction in plant growth rate in relation to water salinity can be a result of a set of factors, such as, the deviation of the metabolic energy for being invested in the maintenance of stressed plant, which represents metabolic cost related to plant adaptation to salinity (Taiz \& Zeiger, 2003), the decrease in $\mathrm{CO}_{2}$ fixation due to an inadequate photosynthetic rate, reduced in relation to a leaf area reduction, and to an increase in respiration due to the stress condition. Reductions in TCAMF, TCAMS and TCRMS in relation to salinity stress were also verified for other crops, such as jatropha by Cunha (2009) and coriander cv. Tabocas and Verdão by Lima (2008), considering that these reductions can vary according to the tolerance and sensitivity of the
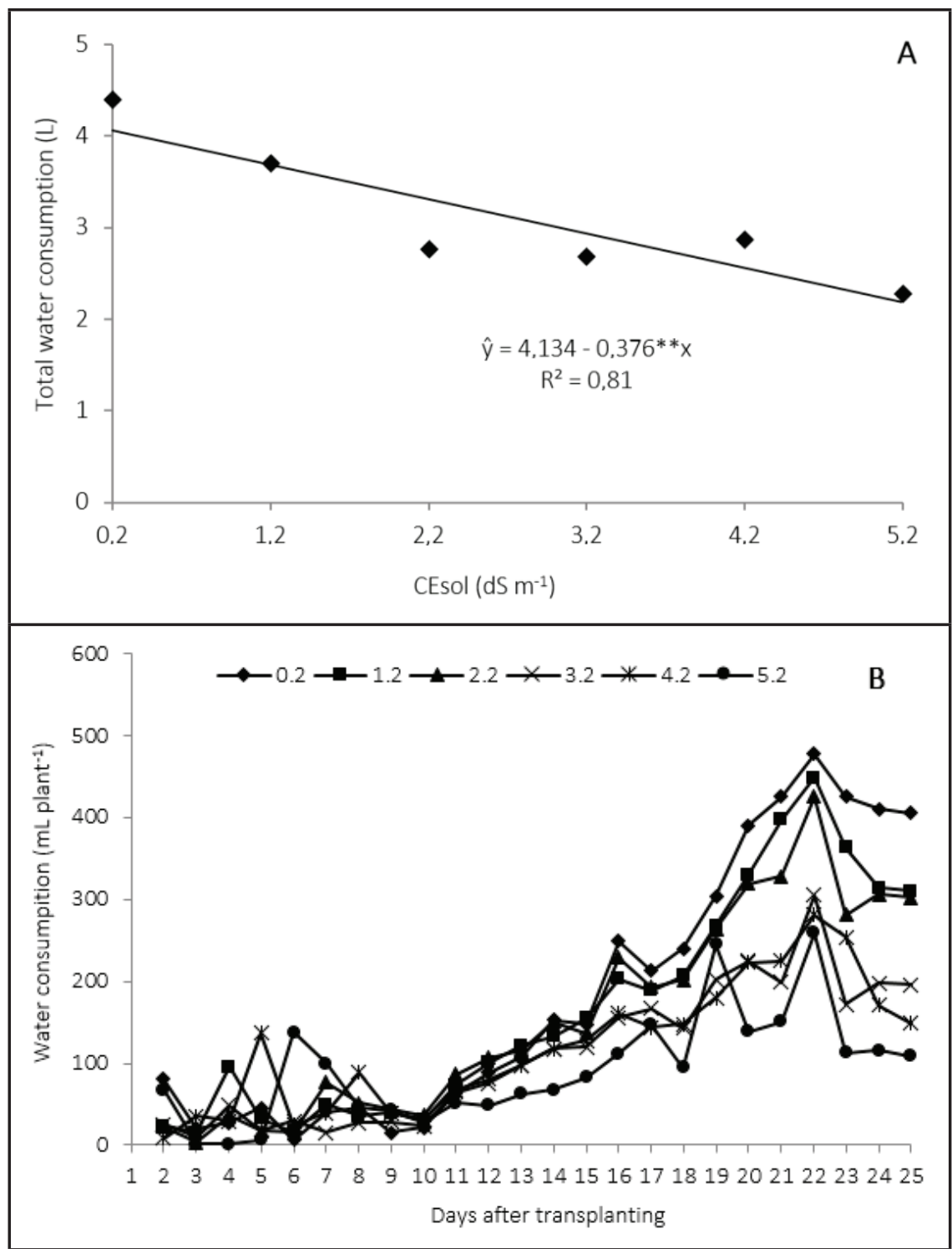

Figure 2. Total water consumption (A) of watercress plant in relation to the levels of water salinity $(\mathrm{CEw})$ and, water consumption during the cycle $(\mathrm{B})$ in relation to the days after transplanting. Recife, UFRPE, 2012. 
cultivars.

A decrease in shoot fresh and dry masses could be noticed when using brackish water, only 10.97 and $10 \%$, respectively (Table 1), and because of that, the authors concluded that it is quite possible to use this water to produce watercress in hydroponic system, since no visual effect of salinity in plants was noticed. These plants showed suitable sizes for commercialization, between 10 and $20 \mathrm{~cm}$ length (ISLA, 2002). Since watercress is commercialized in bunches weighing $100 \mathrm{~g}$, only a greater quantity of plants is necessary to reach this weight. However, when using brackish water, it is possible to increase this production for those producers who have brackish water availability and restricted freshwater availability, avoiding inappropriate disposal of these waters into the soil, resulting in greater environmental control and fresh water preservation.

The increase of salinity of the nutrient solution provided decreasing linear effect on water consumption of the crop, thus the authors verified average water consumption of $61.68 \mathrm{~mL}^{\text {day }}{ }^{-1}$ when using non-brackish water $(0.2$ $\mathrm{dS} \mathrm{m}{ }^{-1}$ ) and $53.24 \mathrm{~mL}$ day $^{-1}$ for greater salinity level $\left(5.2 \mathrm{dS} \mathrm{m}^{-1}\right)$ (Figure 2A). At the end of the cycle, the total plant water uptake (Figure 2A) with no use of brackish water was of $4.06 \mathrm{~L}$ and for those submitted to greater salinity level, reached $2.18 \mathrm{~L}$.

The reduction of water consumption of the crop during the cycle was of $9.1 \%$ per unit increase in water salinity in $\mathrm{dS}$ $\mathrm{m}^{-1}$ (Figure 2A). This reduction was caused probably due to physiological mechanisms induced by saline stress, which affect watercress growth and development, reducing transpiration losses, as concluded by Silva et al. (2012).

Referring to water consumption of watercress crop throughout the cycle (Figure 2B), the authors verified that during the first ten days after transplanting (DAT) the plants showed practically constant consumption. However, after this period, an increase in water consumption was observed together with the vegetative development of the crop for most of salinity levels of nutrient solution, up to 22 DAT. These data show that period of higher water consumption by watercress plants, regardless of the saline concentration of the nutrient solution, is from 10 to 22 DAT.

The authors did not observe deficiency and/or toxicity symptoms in plants, except for the dark green color of leaves under higher salinity levels, possibly, due to the accumulation of $\mathrm{NaCl}$ used when preparing the nutrient solution; since the increase of saline concentration in the solution can provide an increase in chlorophyll content (Mendonça et al., 2010). Soares et al. (2007), using brackish water to grow hydroponic lettuce, reported that the lettuce plants submitted to greater salinity levels $\left(9.08 \mathrm{dS} \mathrm{m}^{-1}\right)$ showed dark green color.

Contents of $\mathrm{P}, \mathrm{K}, \mathrm{Na}$ and $\mathrm{Cl}$ in shoots were influenced by the increase of salinity in the solution, in which the average concentrations found were $7.58 ; 79.13 ; 37.63$ and $1.502 \mathrm{~g} \mathrm{~kg}^{-1}$, respectively. On the other hand, the increase of this salinity did not influence the contents of $\mathrm{N}, \mathrm{Ca}, \mathrm{Mg}$ and $\mathrm{S}$, which average values found were $46.77 ; 2.0$; 6.95 and $3.30 \mathrm{~g} \mathrm{~kg}^{-1}$, respectively. The highest contents of $\mathrm{P}$ (Figure 3A) and $\mathrm{Na}$ (Figure 3B) in the shoots were 8.53 and $60.6 \mathrm{~g} \mathrm{~kg}^{-1}$, respectively, and the minimum values were $6.62 \mathrm{~g} \mathrm{~kg}^{-1}$ for $P$ and $14.61 \mathrm{~g} \mathrm{~kg}^{-1}$ for $\mathrm{Na}$. The results for $\mathrm{P}$ content in the shoot, obtained in this study, are within the concentration range considered appropriate $\left(7-13 \mathrm{~g} \mathrm{~kg}^{-1}\right)$ for good growth and development of the watercress (Silva, 1999).

The increase of $\mathrm{P}$ content in the shoot when salinity is increased could have happened due to a greater need of the crop for this nutrient under stress conditions, since under these conditions some crops increase their need for $\mathrm{P}$ for energy storage, transport performances and carbohydrate partitioning (Paulus et al., 2012).

On the other hand, the increase of $\mathrm{Na}$ content in the plant in relation to the increase of salt concentration in the nutrient solution (Figure 3B), is due to $\mathrm{NaCl}$ used in the preparation of the different treatments, influencing the uptake and accumulation of $\mathrm{NaCl}$ in the plant. According to Helbel Júnior et al. (2007), plants show higher nutrient uptake in high concentrations of this nutrient in the nutrient solution. The same situation was observed for ion $\mathrm{Na}$ in this study, although it is not considered a nutrient for watercress.

The increase in salinity level from 0.2 to $5.2 \mathrm{dS} \mathrm{m}^{-1}$ in the water resulted in a reduction of $\mathrm{K}$ in the shoot of 198\% (Figure 3C). Evaluating the nutrient extraction by lettuce crop, using brackish water for preparing and replacing the nutrient solution, Paulus et al. (2012) also verified reduction of $\mathrm{K}$ absorption, when $\mathrm{Na}$ was added into nutrient solution. This fact can be due to the competition by nutrient absorption sites in the plasmalemma, or a possible increase in $\mathrm{K}$ efflux from roots in the solution, in relation to disturbances of membrane integrity caused by the solution salinity. Decrease in K absorption as a result of an increase of salinity in nutrient solution was also reported by Gondim et al. (2010), evaluating electrical conductivities between 0.5 and $4.0 \mathrm{dS} \mathrm{m}^{-1}$. These authors verified that the highest salt concentrations $\left(4.0 \mathrm{dS} \mathrm{m}^{-1}\right)$ were the ones which contributed to the highest reduction in $\mathrm{K}$ contents in the shoot of lettuce.

Despite the reduction of the $\mathrm{K}$ content in the shoot area, this nutrient was the most accumulated by watercress, estimated average of $79.1 \mathrm{~g} \mathrm{~kg}^{-1}$ (Figure 3C). Regardless of the salinity level of the nutrient solution, $\mathrm{K}$ contents in the shoot were within the concentration range considered appropriate by Silva (1999) for a good growth and development of the crop, which is from 40 to $80 \mathrm{~g} \mathrm{~kg}^{-1}$.

In relation to $\mathrm{Cl}^{-}$, the increased salinity level of nutrient solution provided significant increases in their contents in watercress shoot, with maximum accumulation under $\mathrm{CEw}$ of $4.02 \mathrm{dS} \mathrm{m}^{-1}$ (Figure 3D); values lower than this may be considered defense mechanism in plants under saline stress (Soares et al., 2016).

For Taiz \& Zeiger (2003), salt absorption by the plants depends on the capacity of roots to avoid potentially 


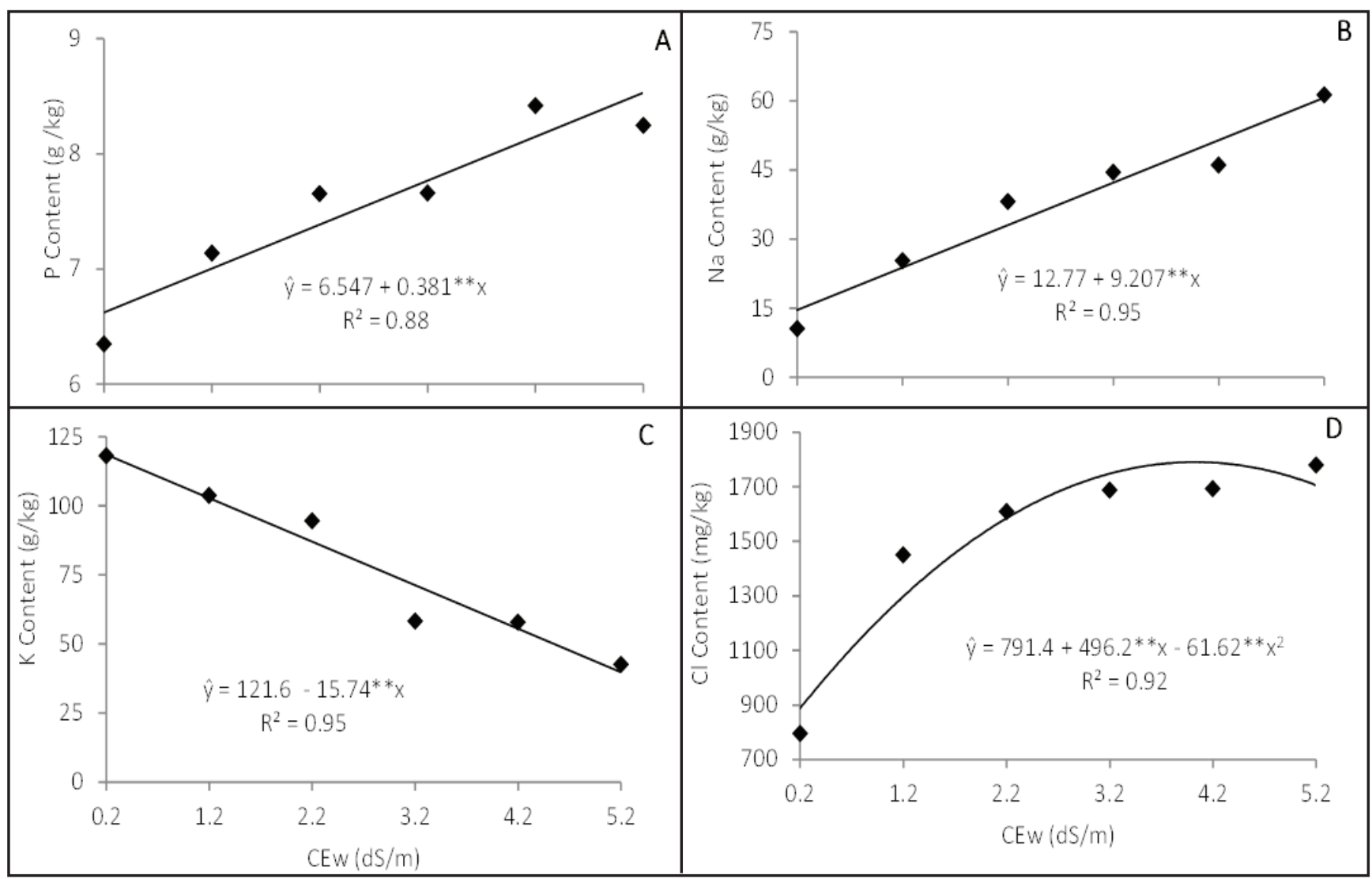

Figure 3. Contents of phosphorus $(\mathrm{P})(\mathrm{A})$, sodium $(\mathrm{Na})(\mathrm{B})$, potassium $(\mathrm{K})(\mathrm{C})$ and chloride $\left(\mathrm{Cl}^{-}\right)(\mathrm{D})$ in the plant shoot, in relation to the levels of water salinity (CEw). Recife, UFRPE, 2012.

damaging ions such as $\mathrm{Cl}^{-}$reaching the shoot area. Na penetrates the roots in a forceful manner forcing them to actively expel it back into the outer solution. On the other hand, $\mathrm{Cl}^{-}$is expelled by the negative electrical potential through the cell membrane and reduces the permeability of the plasma membranes of the root for this ion.

Most plants show $\mathrm{Cl}^{-}$uptake rates at higher levels than necessary for their metabolism, considering that the appropriate content is from 1000 to 2000 $\mathrm{mg} \mathrm{kg}^{-1}$ (Taiz \& Zeiger, 2003). However, the authors verified that the average content found in the watercress shoot in this study was not classified neither as being able to induce plant toxicity (Figure 3D) nor to provoke antagonistic effects to other nutrients. In spite of this, the authors noticed no reduction in the $\mathrm{N}, \mathrm{P}$ and $\mathrm{S}$ uptake, which, as mentioned above, showed average concentrations in the shoot area of the plants of 46.77, 7.58 and $3.30 \mathrm{~g} \mathrm{~kg}^{-1}$ respectively. These contents are considered appropriate for good growth and development of the crop, since according to Silva (1999), the appropriate range of these nutrients in the watercress shoot is between $30-40$ $\mathrm{g} \mathrm{kg}^{-1}$ of $\mathrm{N}$, between 4-6 $\mathrm{g} \mathrm{kg}^{-1}$ of $\mathrm{P}$ and between $2-3 \mathrm{~g} \mathrm{~kg}^{-1}$ of $\mathrm{S}$, respectively.

Even with an increase in $\mathrm{Na}$ contents in the shoot area, the authors observed that the consumer who buys watercress grown under the highest level of salinity $\left(5.2 \mathrm{dS} \mathrm{m}^{-1}\right)$, taking into account the shoot dry mass of $1.2 \mathrm{~g}$ per plant or the fresh mass of $18 \mathrm{~g}$ per plant, this consumer will be eating $0.07 \mathrm{~g}$ per plant of $\mathrm{Na}$ and $0.02 \mathrm{~g}$ per plant of $\mathrm{Cl}^{-}$. Considering that the recommended limit of $\mathrm{NaCl}$ is $6 \mathrm{~g}$ a day (Kaplan, 2000; Paulus et al., 2012), we can conclude that the quantity of accumulated $\mathrm{NaCl}$ in the watercress shoot do not present risk to health in relation to contents of $\mathrm{Na}$ and $\mathrm{Cl}^{-}$quantified in the plants.

Use of brackish water for preparing the nutrient solution and for replacing the evapotranspirated water depth results in reduction of leaf area, shoot fresh and dry masses, the water use of the crop, with an increase of water salinity. The increase in water salinity level used to prepare the nutrient solution up to $5.2 \mathrm{dS}$ $\mathrm{m}^{-1}$ provides significant increases in leaf contents of $\mathrm{P}, \mathrm{Na}$ and $\mathrm{Cl}$ and reduction in $\mathrm{K}$ content. Despite the reduction of $10 \%$ in dry mass through a unit increase in water electrical conductivity in $\mathrm{dS} \mathrm{m}{ }^{-1}$, the authors concluded that it is possible to use brackish water for producing watercress hydroponically as an alternative for the producers who have an availability of brackish water and restricted freshwater availability.

\section{REFERENCES}

ABRACEN. 2015, 16 de janeiro de 2017. Agrião. Disponível em: http://abracen.org.br/abracen/ agriao-pode-ser-preparado-de-diversasformas/\#.WHy9QPkrLcs

ALVES, MS; SOARES, TM; SILVA, LT; FERNANDES, JP; OLIVEIRA, MLA; PAZ, VPS. 2011. Estratégias de uso de água salobra na produção de alface em hidroponia NFT. Revista Brasileira de Engenharia Agrícola e Ambiental 15: 491-498. 
BENINCASA, MMP. 1988. Análise de crescimento de plantas: noções básicas. Funep: UNESP. 41p.

BEZERRA NETO, E; BARRETO, LP. 2011. Análises químicas e bioquímicas em plantas. Recife: UFRPE. 267p.

CUNHA, PC. 2009. Aspectos fisiológicos e bioquímicos de Jatrofha curcas L. cultivada sob estresse salino. Recife: UFRPE. 60p. (Dissertação mestrado).

FILGUEIRA, FAR. 2008. Novo manual de olericultura: Agrotecnologia moderna na produção e comercialização de hortaliças. Viçosa: UFV. 421p.

FURLANI, PR. 1998. Instruções para o cultivo de hortaliças de folhas pela técnica de hidroponia NFT. Campinas: IAC. 30p. (Boletim Técnico, 168).

GOMES, LO. 2009. Resposta da cultura do agrião à salinidade utilizando um sistema hidropônico do tipo NFT. Piracicaba: USPESALQ. 67p. (Dissertação mestrado).

GONDIM, ARO; FLORES, MEP; MARTINEZ, HEP; FONTES, PCR; PEREIRA, PRG. 2010. Condutividade elétrica na produção e nutrição de alface em sistema de cultivo hidropônico NFT. Bioscience Journal 26: 894-904.

HELBEL JÚNIOR, C; REZENDE, R; FRIZZONE, JA; SANTOS, HS; DALLACORT, R. 2007. Produção hidropônica da cultura da alface com soluções nutritivas e vazões distintas. Acta Scientiarum 29: 391-395.

ISLA. 2002. Catálogo 2001/2002. Porto Alegre: Isla Sementes.

KAPLAN, NM. 2000. The dietary guideline for sodium: should we shake it up? No. The American Journal of Clinical Nutrition 71: 1020-1026.

LIMA, AB. 2008. Respostas fisiológicas e bioquímicas de cultivares de coentro (Coriadrum sativum L.) submetidas ao estresse salino. Recife: UFRPE. 55p. (Dissertação mestrado).

MACIEL, MP; SOARES, TM; GHEYI, HR; RESENDE, EPL; OLIVEIRA, GXS. 2012. Produção de girassol ornamental com uso de águas salobras em sistema hidropônico NFT. Revista Brasileira de Engenharia Agrícola e Ambiental 16: 165-172.

MARTINEZ, HEP. 2002. O uso do cultivo hidropônico de plantas em pesquisa. Viçosa: UFV. 61p. (Caderno Didático, n.1).

MENDONÇA, AVR; CARNEIRO, JGA FREITAS, TAS; BARROSO, DG. 2010 Características fisiológicas de mudas de Eucalyptus spp. submetidas a estresse salino. Revista Ciência Florestal 20: 255-267.

OHSE, S; CARVALHO, SM; RESENDE, BLA; OLIVEIRA, JB; MANFRON, PA; DOURADO NETO, D. 2012. Produção e composição química de hortaliças folhosas em hidroponia. Bioscience Journal 28: 155-163.

PAULUS, D; DOURADO NETO, D; FRIZZONE, JA; SOARES, TM. 2010. Produção e indicadores fisiológicos de alface sob hidroponia com água salina. Horticultura Brasileira 28: 29-35.

PAULUS, D; PAULUS, E; NAVA, GA; MOURA, CA. 2012. Crescimento, consumo hídrico e composição mineral de alface cultivada em hidroponia com águas salinas. Revista Ceres 59: 110-117.

SANTOS, AN; SOARES, TM; SILVA, EFF; SILVA, DJR; MONTENEGRO, AAA. 2010 Cultivo hidropônico de alface com água salobra subterrânea e rejeito da dessalinização em Ibimirim, PE. Revista Brasileira de Engenharia Agrícola e Ambiental 14: 961-969.
SILVA JÚNIOR, GS. 2007. Respostas biométricas, ecofisiológicas e nutricionais em genótipos diplóides de bananeira (Musa spp.) submetidos à salinidade. Recife: UFRPE. 106p. (Tese doutorado).

SILVA, AO; SOARES, TM; SILVA, EFF; SANTOS, AN; KLAR, AE. 2012. Consumo hídrico da rúcula em cultivo hidropônico NFT utilizando rejeitos de dessalinizador em Ibimirim-PE. Irriga 17: 114-125.

SILVA, FC. (org.). 1999. Manual de análises químicas de solos, plantas e fertilizantes. Rio de Janeiro/Campinas: Embrapa Solos/ Embrapa Informática Agropecuária. 370p.

SOARES, HH; SILVA, EFF; SILVA, GF; LIRA, RM; BEZERRA, RR. 2016. Mineral nutrition of crisphead lettuce grown in a hydroponic system with brackish water. Revista Caatinga 29: 656-664.

SOARES, TM; DUARTE, SN; SILVA, EFF; JORGE, CA. 2010. Combinação de águas doce e salobra para a produção de alface hidropônica. Revista Brasileira de Engenharia Agrícola e Ambiental 14: 705-714.

SOARES, TM; DUARTE, SN; SILVA, EFF; MÉLO, RF; JORGE, CA; OLIVEIRA, AS. 2009. Experimental structure for evaluation of brackish water use in lettuce hydroponic production. Irriga 14: 102-114.

SOARES, TM; SILVA, EFF; DUARTE, SN; MÉLO, RF; JORGE, CA; BONFIM-SILVA, EM. 2007. Produção de alface utilizando águas salinas em sistema hidropônico. Irriga 12: $235-248$.

TAIZ, L; ZEIGER, E. 2003. Plant physiology. 3 ed. Artmed. 720p. 